\title{
Pengaruh Tingkat Persepsi Masyarakat Kecamatan Dolok Silau terhadap Realisasi Rencana Pemekaran di Kabupaten Simalungun
}

\section{Effect of the Level of Perception of the District of Dolok Silau on the Realization of the Expansion Plan in Simalungun District Rohani Silalahi*1), Muhammad Husni Thamrin Nasution ${ }^{2)}$} Armansyah Matondang3)

1) Program Studi Ilmu Pemerintahan, Fakultas Ilmu Sosial dan Ilmu Politik Universitas Medan Area, Indonesia

2) Program Studi Administrasi Publik, Fakultas Ilmu Sosial dan Ilmu Politik Universitas Medan Area, Indonesia

3) Program Studi Ilmu Komunikasi, Fakultas Ilmu Sosial dan Ilmu Politik Universitas Medan Area, Indonesia

Diterima: Mei 2019; Disetujui: Juni 2019; Dipublish: Juli 2019

\begin{abstract}
Abstrak
Pemekaran wilayah kabupaten merupakan merupakan suatu terobosan untuk meningkatkan pembangunan di suatu daerah lebih cepat baik melalui peningkatan kualitas dan kuantitas. Pemekaran wilayah ini memberikan batasan pengawasan sehingga pemerintah bisa mengontrol daerah lebih sempit menjadi lebih fokus. Hal inilah yang mendasari keinginan masyarakat untuk merencanakan pemekaran. Dengan demikian maka dapat diambil rumusan masalah adalah apakah ada pengaruh tingkat persepsi masyarakat kecamatan Dolok Silau terhadap realisasi rencana pemekaran di Kabupaten Simalungun dengan tujuan untuk mengetahui adakah pengaruh tingkat persepsi masyarakat kecamatan Dolok Silau terhadap realisasi rencana pemekaran di kabupaten simalungun dan untuk mengetahui seberapa besar pengaruh tingkat persepsi masyarakat kecamatan Dolok silau terhadap realisasi rencana pemekaran di Kabupaten Simalungun. Bentuk penelitian ini adalah dengan menggunakan penelitian deskriptif dengan pendekatan kuantitatif dengan maksud untuk mencari pengaruh antara variabel X (bebas) dengan variabel Y (terikat). Penelitian ini dilakukan di kecamatan Dolok Silau Kabupaten Simalungun. Sedangkan pengumpulan data dilakukan dengan cara menyebarkan kuesioner, wawancara dan observasi.
\end{abstract}

Kata Kunci : Persepsi Masyarakat, Realisasi Pemekaran

\begin{abstract}
Blossoming district is a breakthrough to boost development in a region more quickly either through an increase in quality and quantity. This blossoming gives supervision so that the government can control the narrower region is becoming more focused. This is the underlying desire of the community to plan for expansion. Thus can be taken the formulation of the problem is whether there is influence of the level of public perception of the subdistrict dolok silau realizations against plans expansion in simalungun regency with the aim to know is there any influence the level of perception dolok sub society glare towards the realization of the plan of expansion in simalungun and to know how much influence the public perception of the subdistrict level Doloksilau againts the realization of the plan of expansion in simalungun. The form of this research is to use descriptive research with quantitative approach with a view to seeking influences between variables $X$ (free) with the variable $Y$ (tied). This research was conducted in the Doloksilau, simalungun Regency glare. While the collection of data is carried out by means of disseminating the questionnaire, interview and observation.
\end{abstract}

Keywords: Public Perception, Realization of The Expansion

How to Cite: Silalahi, R, Thamrin, \& Matondang, A. (2019). Pengaruh Tingkat Persepsi Masyarakat Kecamatan Dolok Silau terhadap Realisasi Rencana Pemekaran di Kabupaten Simalungun. PERSPEKTIF, 8 (2): 39-44.

*Corresponding author:

E-mail: rohanisilalahi7788@gmail.com

ISSN 2085-0328 (Print) 


\section{PENDAHULUAN}

Era reformasi telah memberikan ruang yang lebih terbuka kepada masyarakat untuk menguatkan otonomi daerah, sebagai salah satu produk dari era reformasi. Otonomi daerah merupakan strategi untuk merespon tuntutan masyarakat untuk mengembangkan dan membangun dirinya sendiri. Keinginan tersebut didasari terjadinya dinamika di daerah itu sendiri baik dinamika sosial, ekonomi, politik maupun budaya (Suharyanto, dkk, 2017)

Sistem pemerintahan yang ada diera otonomi daerah saat ini dengan asas desentralisasi merupakan suatu refleksi proses reformasi sosial, ekonomi, politik maupun budaya di Indonesia memiliki kecenderungan dan pergeseran pelayanan publik dari wewenang pemerintah pusat menjadi wewenang pemerintah daerah yang lebih dekat dengan masyarakatnya. Salah satunya adalah dengan adanya respon pemerintah pusat terhadap pemekaran wilayah melalui UU No.23 Tahun 2014 tentang pemerintahan daerah.

Pelaksanaan otonomi daerah merupakan titik fokus yang penting dalam rangka memperbaiki kesejahteraaan rakyat. Pengembangan suatu daerah dapat disesuaikan oleh pemerintah daerah dengan potensi dan kekhasan daerah masing-masing. Pembentukan daerah otonom yang secara serentak (simultan) merupakan kelahiran status otonomi yang didasarkan atas aspirasi dan kondisi objektif dari masyarakat didaerah/wilayah nasional Indonesia.Aspirasi tersebut terwujud dengan diselenggarakannya desentralisasi kemudian menjelma menjadi daerah otonom.

Selain dari peraturan perundangundangan tersebut, juga adanya wilayah yang terlalu luas dan banyaknya kecamatan untuk dikelola dalam satu wilayah pemerintahan. 31 (tiga puluh satu) Kecamatan yang terdiri dari di wilayah Kabupaten Simalungun tersebut, dimekarkan menjadi 2 (dua) Kabupaten dengan pembagian 16 (enambelas) Kecamatan tetap di kabupaten induk dan 15 (limabelas) Kecamatan di kabupaten pemekaran. Pemekaran Kabupaten Simalungun tersebut menjadi wajar dengan harapan akan membawa berbagai keuntungan bagi masyarakat, seperti fasilitas sosial, ekonomi dan finansial untuk kepentingan kesejateraan masyarakat pada masa depan bagi daerah yang baru dimekarkan (Suharyanto, 2017)

Kabupaten induk Simalungun yang beribu kota di Pematang Raya, terdiri dari 16 (enambelas) Kecamatan, yaitu: Kecamatan Raya, Purba, Haranggaol Horisan, Haranggaol, Dolok Panribuan, Dolok Pardamaean, Girsang Sipanganbolon, Sidamanik, Pematang Sidamanik, Panombean Panei, Panei, Raya Kahean, Dolok Silau, Silimakuta, Pematang Silimahuta dan Jorlang Hataran. 15 (limabelas) Kecamatan lainnya nantinya di kabupaten pemekaran yang beribukota di Perdagangan, yaitu: Siantar, Gunung Maligas, Gunung Malela, Tapian Dolok, Dolok Batu Nanggar, Bandar Huluan, Bandar Masulam, Pematang Bandar, Bandar, Bosar Maligas, Ujung Padang, Hutabayu Raja, Jawa Maraja Bahjambi, Tanah Jawa dan Hatonduhan (Lubis, 1996) (Lubis, 2014).

Partisipasi politik merupakan kegiatan yang dilakukan warga negara untuk terlibat dalam proses pengambilan keputusan yang dilakukan pemerintah. (Kusmanto, 2013). Partisipasi politik adalah bagian penting dalam kehidupan politik suatu negara, terutama bagi negara yang menyebut dirinya sebagai negara demokrasi, partisipasi politik merupakan salah satu indikator penting (Suharyanto, 2014). Pentingnya partisipasi politik masyarakat berkaitan dengan hak dan kewajiban individu atau kelompok sebagai warga negara dalam menggunakan segala sumber daya sosialnya untuk mempengaruhi proses pengambilan keputusan dalam pemerintah (Susi \& Adelita, 2015)

Kegiatan partisipasi politik itu hanyalah kegiatan yang dimaksudkan untuk mempengaruhi pengambilan keputusan pemerintah. Kegiatan yang dimaksud misalnya membujuk atau menekan pejabat pemerintah, untuk bertindak dengan cara-cara tertentu untuk menggagalkan keputusan, bahkan dengan cara berusaha mengubah aspek-aspek sistem politik atau mengubah secara mendasar struktur politik agar pemerintah lebih tanggap terhadap keinginan-keinginan mereka.

Banyaknya aspirasi dan dukungan masayarakat terhadap pembentukan Kabupaten Simalungun Hataran dan banyaknya kesenjangan pembangunan yang terjadi baik dari segi insfrastruktur (jalan yang buruk atau rusak) fasilitas kesehatan, fasilitas pendidikan, yang kurang memadai, pelayanan 
administrasi yang dinilai sangat lambat serta kurangnya tokoh yang menerima aspirasi dari masyarakat. Dengan demikian penulis merasa tertarik untuk melakukan penelitian mengenai Pengaruh tingkat persepsi masyarakat terhadap realisasi rencana pemekaran di Kabupaten Simalungun.

\section{METODE PENELITIAN}

Jenis penelitian Penelitian ini menggunakan pendekatan kuantitatif dengan jenis penelitian deskriptif . Metode penelitian kuantatif dapat diartikan sebagai metode penelitian yang berlandaskan pada filsafat positivisme, digunakan untuk meneliti pada populasi atau sampel tertentu, pengumpulan data menggunakan instrumen penelitian, analisis data bersifat kuantitatif/statistik, dengan tujuan untuk menguji hipotesis yang telah ditetapkan.

Penelitian dilakukan di kecamatan dolok silau kabupaten simalungun populasi yang ditentukan dalam penelitian ini adalah seluruh masayarakat yang ada di Kecamatan Dolok Silau yang terdiri dari 4.835 kepala keluarga dan 15698 jiwa yang terbagi atas 14 desa. Menurut Ardial (2014) sampel adalah sebagian dari jumlah dan karakteristik yang dimiliki oleh populasi tersebut.yang dipelajari dari sampel itu kesimpulannya akan diberlakukan untuk populasi.untuk itu, sampel yang diambil dari populasi harus betul-betul representative (mewakili), maka yang akan menjadi sampel responden dalam penelitian ini adalah 98 responden.

Teknik pengumpulan data dilakukan menggunakan kuesioner. Dalam penelitian ini penulis mengemukakan dua variabel yang sangat menentukan dan saling berhubungan. Kedua variabel tersebut adalah Variabel dan Defenisi Operasional

\section{HASIL DAN PEMBAHASAN}

Berdasarkan hasil pengolahan angket 39 orang atau $39,8 \%$ yang menjawab sangat setuju, sebanyak 42 orang atau $42,9, \%$ yang menjawab setuju, sebanyak 5 orang atau 5,1\% yang menjawab ragu- ragu, sebanyak 7 orang atau $7,1 \%$ yang menjawab tidak setuju dan sebanyak 5 orang atau 5,1 \% yang menjawab sangat tidak setuju.dari data tersebut dapat kita lihat bahwa mayoritas responden menjawab setuju mengenai kebijakan rencana pemekaran dikabupaten simalungun.
Berdasarkan hasil pengeolahan angket sebanyak 19 orang atau 19,4\% yang menjawab sangat setuju, sebanyak 44 orang atau $44,9 \%$ yang menjawab setuju, sebanyak 22 orang atau $22,4 \%$ yang menjawab ragu- ragu, sebanyak 7 orang atau 7,1\% yang menjawab tidak setuju dan sebanyak 6 orang atau $6,1 \%$ yang menjawab sangat tidak setuju.Dari data tersebut dapat dilihat bahwa mayoritas responden menjawab setuju yaitu $44,9 \%$ .setuju terhadap pemekaran dikabupaten simalungun benar-benar terwujud atau terealisasi.

Berdasarkan hasil pengolahan angket 14 orang atau $14,3 \%$ yang menjawab sangat setuju, sebanyak 39 orang atau 39,8\% yang menjawab setuju, sebanyak 29 orang atau $29,6 \%$ yang menjawab ragu- ragu, sebanyak 10 orang atau $10,20 \%$ yang menjawab tidak setuju dan sebnayak 6 orang atau 6,1\% yang menjawab sangat tidak setuju.Dari data tersebut dapat kita lihat bahwa mayoritas responden menjawab setuju terhadap rencana pemekaran dikabupaten simalungun berguna untuk masyarakat.

Berdasarkan hasil pengolahan angket 10 orang atau $10,2 \%$ yang menjawab sangat setuju, sebanyak 39 orang atau 39,8\% yang menjawab setuju, sebanyak 31 orang atau $31,6 \%$ yang menjawab ragu- ragu, sebanyak 12 orang atau $12,2 \%$ yang menjawab tidak setuju dan sebnayak 6 orang atau 6,1\% yang menjawab sangat tidak setuju. Dari data tersebut dapat kita lihat bahwa mayoritas responden menjawab setuju terhadap rencana pemekaran dikabupaten simalungun merupakan suatu kebutuhan bagi masyarakat simalungun.

Berdasarkan hasil pengolahan angket 10 orang atau $10,2 \%$ yang menjawab sangat setuju, sebanyak 39 orang atau 39,8\% yang menjawab setuju, sebanyak 31 orang atau $31,6 \%$ yang menjawab ragu- ragu, sebanyak 12 orang atau $12,2 \%$ yang menjawab tidak setuju dan sebnayak 6 orang atau 6,1\% yang menjawab sangat tidak setuju.Dari data tersebut dapat kita lihat bahwa mayoritas responden menjawab setuju terhadap rencana pemekaran dikabupaten simalungun merupakan suatu kebutuhan bagi masyarakat Simalungun.

Berdasarkan hasil pengolahan angket 10 orang atau $10,2 \%$ yang menjawab sangat setuju, sebanyak 38 orang atau 38,8\% yang 
menjawab setuju, sebanyak 26 orang atau $26,5 \%$ yang menjawab ragu- ragu, sebanyak 18 orang atau $18,4 \%$ yang menjawab tidak setuju dan sebnayak 6 orang atau 6,1\% yang menjawab sangat tidak setuju.Dari data tersebut dapat kita lihat bahwa mayoritas responden menjawab setuju dengan terwujudnya pemekaran kabupaten simalungun nantinya mampu memberikan kemudahan dalam mendukung aktifitas perekonomian saudara.

Berdasarkan hasil pengolahan angket 8 orang atau 8,2\% yang menjawab sangat setuju, sebanyak 41 orang atau 41,8\% yang menjawab setuju, sebanyak 30 orang atau 30,6\% yang menjawab ragu- ragu, sebanyak 14 orang atau $14,3 \%$ yang menjawab tidak setuju dan sebnayak 5 orang atau 5,1\% yang menjawab sangat tidak setuju.Dari data tersebut dapat kita lihat bahwa mayoritas responden menjawab setuju jika nantinya pemekaran simalungun terwujud tidak terdapat hambatan-hambatan yang menyulitkan saudara dalam melakukan aktifitas perekonomian.

Berdasarkan hasil pengolahan angket 10 orang atau 10,2\% yang menjawab sangat setuju, sebanyak 51 orang atau 51,0\% yang menjawab setuju, sebanyak 20 orang atau 20,4\% yang menjawab ragu- ragu, sebanyak 13 orang atau 13,3\% yang menjawab tidak setuju dan sebnayak 4 orang atau 4,1\% yang menjawab sangat tidak setuju.Dari data tersebut dapat kita lihat bahwa mayoritas responden menjawab setuju dengan terwujudnya pemekaran simalungun nantinya akan memudahkan segala urusan administrasi mudah dan cepat.

Berdasarkan hasil pengolahan angket 7 orang atau 7,1\% yang menjawab sangat setuju, sebanyak 40 orang atau 40,8\% yang menjawab setuju, sebanyak 33 orang atau 33,7\% yang menjawab ragu- ragu, sebanyak 14 orang atau $14,3 \%$ yang menjawab tidak setuju dan sebnayak 4 orang atau 4,1\% yang menjawab sangat tidak setuju.Dari data tersebut dapat kita lihat bahwa mayoritas responden menjawab setuju terhadap pelayanan kepada masyarakat akan semakin baik jika nantinya pemekaran simalungun terwujud .

Berdasarkan hasil pengolahan angket 8 orang atau 8,2\% yang menjawab sangat setuju, sebanyak 33 orang atau 33,7\% yang menjawab setuju, sebanyak 29 orang atau 29,6\% yang menjawab ragu- ragu, sebanyak 24 orang atau $24,5 \%$ yang menjawab tidak setuju dan sebnayak 4 orang atau 4,1\% yang menjawab sangat tidak setuju.Dari data tersebut dapat kita lihat bahwa mayoritas responden menjawab ragu-ragu terhadap sarana dan prasarana akan semakin memadai jika nantinya pemekaran Simalungun terwujud.

Berdasarkan hasil pengolahan angket 11 orang atau 11,2\% yang menjawab sangat setuju, sebanyak 33 orang atau 33,7\% yang menjawab setuju, sebanyak 35 orang atau $35,7 \%$ yang menjawab ragu- ragu, sebanyak 15 orang atau 15,3\% yang menjawab tidak setuju dan sebnayak 4 orang atau 4,1\% yang menjawab sangat tidak setuju.Dari data tersebut dapat kita lihat bahwa mayoritas responden menjawab setuju jika nantinya pemekaran simalungun terwujud pemerintah daerah semakin fokus dalam meningkatkan pembangunan insfrastruktur di daerah khususnya di daerah pedesaan.

Berdasarkan hasil pengolahan angket 14 orang atau 14,3\% yang menjawab sangat setuju, sebanyak 37 orang atau 37,8\% yang menjawab setuju, sebanyak 27 orang atau $27,6 \%$ yang menjawab ragu- ragu, sebanyak 15 orang atau 15,3\% yang menjawab tidak setuju dan sebnayak 5 orang atau 5,1\% yang menjawab sangat tidak setuju. Dari data tersebut dapat kita lihat bahwa mayoritas responden menjawab setuju jika nantinya pemekaran simalungun terwujud pembangunan di daerah anda memiliki peningkatan.

Berdasarkan hasil pengolahan angket 7 orang atau 7,1\% yang menjawab sangat setuju, sebanyak 39 orang atau 39,8\% yang menjawab setuju, sebanyak 29 orang atau 29,6\% yang menjawab ragu- ragu, sebanyak 19 orang atau $19,4 \%$ yang menjawab tidak setuju dan sebnayak 4 orang atau 4,1\% yang menjawab sangat tidak setuju.Dari data tersebut dapat kita lihat bahwa mayoritas responden menjawab setuju jika nantinya pemekaran simalungun terwujud maka dapat membantu tingkat ekonomi di daerah anda.

Berdasarkan hasil pengolahan angket 7 orang atau 7,1\% yang menjawab sangat setuju, sebanyak 37 orang atau 37,8\% yang menjawab setuju, sebanyak 28 orang atau 28,6\% yang menjawab ragu- ragu, sebanyak 18 orang atau $18,4 \%$ yang menjawab tidak setuju dan sebnayak 8 orang atau 8,2\% yang menjawab 
sangat tidak setuju.Dari data tersebut dapat kita lihat bahwa mayoritas responden menjawab setuju terhadap tingkat pendapatan masyarakat akan semakin baik jika nantinya pemekaran simalungun terwujud

Berdasarkan hasil pengolahan angket 8 orang atau $8,2 \%$ yang menjawab sangat setuju, sebanyak 42 orang atau $42,9 \%$ yang menjawab setuju, sebanyak 27 orang atau $27,6 \%$ yang menjawab ragu- ragu, sebanyak 15 orang atau $15,3 \%$ yang menjawab tidak setuju dan sebnayak 6 orang atau 6,1\% yang menjawab sangat tidak setuju.Dari data tersebut dapat kita lihat bahwa mayoritas responden menjawab setuju terhadap fasilitas pendidikan akan semakin meningkat di daerah khususnya di pedesaan jika pemekaran simalungun terwujud.

Berdasarkan hasil pengolahan 12 orang atau $12,2 \%$ yang menjawab sangat setuju, sebanyak 43 orang atau $43,9 \%$ yang menjawab setuju, sebanyak 22 orang atau $22,4 \%$ yang menjawab ragu- ragu, sebanyak 17 orang atau $17,3 \%$ yang menjawab tidak setuju dan sebnayak 4 orang atau 4,1\% yang menjawab sangat tidak setuju.Dari data tersebut dapat kita lihat bahwa mayoritas responden menjawab setuju jika nantinya pemekaran simalungun terwujud pelayanan kesehatan terutama pengadaan sarana kesehatan akan meningkat.

Berdasarkan hasil pengolahan angket 7 orang atau $7,1 \%$ yang menjawab sangat setuju, sebanyak 40 orang atau $40,8 \%$ yang menjawab setuju, sebanyak 33 orang atau $33,7 \%$ yang menjawab ragu- ragu, sebanyak 14 orang atau $14,3 \%$ yang menjawab tidak setuju dan sebnayak 4 orang atau $4,1 \%$ yang menjawab sangat tidak setuju.Dari data tersebut dapat kita lihat bahwa mayoritas responden menjawab setuju jika nantinya pemekaran simalungun terwujud maka kesejahteraan masyarakat di daerah akan meningkat.

Berdasarkan hasil pengolahan angket 12 orang atau $12,2 \%$ yang menjawab sangat setuju, sebanyak 41 orang atau $41,8 \%$ yang menjawab setuju, sebanyak 25 orang atau $25,5 \%$ yang menjawab ragu- ragu, sebanyak 13 orang atau $13,3 \%$ yang menjawab tidak setuju dan sebnayak 7 orang atau 7,1\% yang menjawab sangat tidak setuju.Dari data tersebut dapat kita lihat bahwa mayoritas responden menjawab setuju jika nantinya pemekaran simalungun terwujud aspirasi/keluhan masyarakat di bidang sarana dan prasarana insfrastruktur di daerah khususnya pedesaan lebih mudah disampaikan.

Berdasarkan hasil pengolahan angket 9 orang atau 9,2\% yang menjawab sangat setuju, sebanyak 38 orang atau $38,8 \%$ yang menjawab setuju, sebanyak 28 orang atau $28,6 \%$ yang menjawab ragu- ragu, sebanyak 18 orang atau $18,4 \%$ yang menjawab tidak setuju dan sebnayak 5 orang atau 5,1\% yang menjawab sangat tidak setuju.Dari data tersebut dapat kita lihat bahwa mayoritas responden menjawab setuju jika nantinya pemekaran simalungun terwujud hubungan antara pemerintah daerah dengan pemerintah pusat akan semakin serasi

\section{SIMPULAN}

Dari perhitungan koefisien korelasi product moment diperoleh rhitung sebesar 0.846 yang berarti terdapat hubungan antara variabel tingkat persepsi masyarakat kecamatan dolok silau (X) dengan variabel realisasi rencana pemekaran kabupaten simalungun (Y) dan tingkat hubungannya sangat kuat.

Dari perhitungan di atas diketahu nilai koefisien korelasi product moment adalah sebesar 0,846. Sedangkan berdasarkan $r$ tabel product moment untuk n 98 pada taraf signifikansi $10 \%$ diperoleh nilai $0,25 \%$. Karena nilai $r$ hitung $(0,846)$ lebih besar dari nilai $r$ tabel $(0,25 \%)$ maka hubungan kedua variabel tersebut dianggap signifikan. Hal ini berarti ada hubungan yang positif antara tingkat persepsi masyarakat kecamatan dolok silau terhadap realisasi rencana pemakaran kabupaten simalungun. Tingkat persepsi masyarakat Kecamatan Dolok Silau memberikan pengaruh yang positif dan pengaruh yang besar terhadap Realisasi Rencana Pemekaran di Kabupaten

Simalungun. Dengan terealisasinya pemekaran di Kabupaten Simalungun dapat memberikan pengaruh yang besar kepada masyarakat kecamatan Dolok Silau yakni dapat meningkatkan kesejahteraan masyarakat Kecamatan Dolok Silau dan seluruh Kabupaten Simalungun. Hal ini juga dapat dilihat pada perhitungan uji determinan yang bahwa konstribusi pengaruh variabel $\mathrm{X}$ (tingkat persepsi masyarakat kecamatan Dolok Silau) terhadap variabel Y (realisasi rencana 
pemekaran kabupaten simalungun) adalah sebesar $71,57 \%$ sedangkan sisanya sebesar $28,43 \%$ dipengaruhi oleh faktor lain.

Pengaruh tingkat persepsi masyarakat kecamatan Dolok Silau terhadap realisasi rencana pemekaran di kabupaten simalungun adalah positif yang dapat di uji melalui rumus regresi linear sederhana yang diperoleh persamaan $Y=3,501+1,062 X$. Artinya apabila nilai variabel X (Tingkat Persepsi Masyarakat Kecamatan Dolok Silau) dinaikkan sebanyak satu satuan maka nilai variabel $\mathrm{Y}$ (Realisasi Rencana Pemekaran di Kabupaten Simalungun) juga akan meningkat. Hal ini menunjukkan bahwa tingkat persepsi masyarakat Kecamatan Dolok Silau sejalan dengan Realisasi Rencana Pemekaran di Kabupaten Simalungun dan searah dengan Hipotesis yang ada.

\section{DAFTAR PUSTAKA}

Ahmad, J. (2015). Metode Penelitian Administrasi Publik Teori Dan Aplikasi, Yogyakarta: Gava Media.

Ardial, (2014). Paradigma Dan Model Penelitian Komunikasi. Jakarta: Bumi Aksara.

James, A.B \& Dean, J.C. (1993), Metode dan Masalah Penelitian Sosial, Bandung: PT. Eresco

Kaloh. (2007). Mencari Bentuk Otonomi Daerah Suatu Solusi Dalam Menjawab Kebutuhan Lokal Dan Tantangan Global”. Jakarta: PT. Rineka Cipta.

Siagian, S. (1988). Organisasi, Kepemimpinan Dan Perilaku Administrasi. Jakarta: Haji Masagung.

Sugiyono. (2010). Metode Penelitian Kuantitatif Kualitatif dan R\&D”. Bandung: Alfabeta.
Sugiyono. (2012). Metode Penelitian Bisnis. Bandung: Alfabeta

Sugiyono. (2017). Statistika Untuk Penelitian". Bandung: Alfabeta

Saefulhakim. (2004). Pemekaran Daerah, Jakarta: Bumi Aksara

Thoha, M. (2011). Perilaku Organisasi Konsep Dasar Dan Aplikasinya. Jakarta: Rajawali Pers

Widjaja, H. (2002). Otonomi Daerah Dan Daerah Otonom. Jakarta: Rajawali Pers,

Wirotomo, P. (1982). Pokok-Pokok Pikiran Dalam Sosiologi David Berry. Jakarta: Rajawali.

Suharyanto, A., Armansyah M., dan Syafruddin R., (2017). Persepsi Masyarakat Kelurahan Tigabalata Kecamatan Jorlang Hataran mengenai Usulan Pemekaran Kabupaten Simalungun, JUPIIS: Jurnal Pendidikan IlmuIlmu Sosial, 9 (2): 177-185

Kusmanto, H., (2013). Peran Badan Permusyawaratan Daerah dalam Meningkatkan Partisipasi Politik Masyarakat, JPPUMA: Jurnal Ilmu Pemerintahan dan Sosial Politik UMA, 1 (1): 41-47.

Lubis, E, (1996), Peran Serta Masyarakat Dalam Mendukung Pelaksanaan Otonomi Daerah di Kabupaten Simalungun (Skripsi), Universitas Negeri Medan.

Lubis, E, (2014), Studi Antropologi Pemekaran Wilayah Kabupaten Simalungun, Universitas Negeri Medan

Suharyanto, A., (2014). Partisipasi Politik Masyarakat Tionghoa dalam Pemilihan Kepala Daerah, JPPUMA: Jurnal Ilmu Pemerintahan dan Sosial Politik UMA, 2 (2): 166-175

Susi S dan Adelita L., (2015). Partisipasi Politik Perempuan pada Partai Keadilan Sejahtera Kota Medan, JPPUMA: Jurnal Ilmu Pemerintahan dan Sosial Politik UMA, 3 (1): 1-3. 